\title{
TURBIN ANGIN MINI SEBAGAI ALTERNATIF SUMBER ENERGI LISTRIK UNTUK LAMPU NAVIGASI PADA KAPAL PENANGKAP IKAN
}

\author{
Mini Wind Turbine as Alternative Power Source for Navigation Lamps on Fishing Vessel \\ Oleh: \\ Dudi Firmansyah ${ }^{1}$, Fis Purwangka ${ }^{1 *}$, Budhi Hascaryo Iskandar ${ }^{1}$ \\ ${ }^{1}$ Departemen Pemanfaatan Sumberdaya Perikanan FPIK IPB \\ ${ }^{*}$ Korespondensi penulis: fis@psp-ipb.org
}

\begin{abstract}
ABSTRAK
Penelitian ini bertujuan untuk mengetahui pengaruh waktu (siang dan malam) terhadap besarnya kecepatan angin $(\mathrm{km} / \mathrm{jam})$ di daerah penelitian, mengetahui tipe angin berdasarkan kecepatan angin $(\mathrm{km} / \mathrm{jam})$ rata-rata di daerah penelitian menurut tabel skala Beaufort, mengetahui pengaruh jumlah 3 sudu dan 6 sudu pada turbin angin terhadap kecepatan putaran per menit (rpm) alternator, mengetahui perbandingan lama waktu pengisian baterai oleh turbin angin dengan 3 sudu dan 6 sudu, mengetahui waktu yang dibutuhkan untuk menghidupkan rangkaian lampu LED. Penelitian ini dilakukan dengan metode percobaan, yaitu melakukan uji coba turbin angin dengan 3 sudu dan 6 sudu. Analisis data yang digunakan adalah analisis univariat, bivariat dan analisis lanjut. Waktu (siang dan malam) memberikan pengaruh terhadap besarnya kecepatan angin. Turbin angin dengan 6 sudu menghasilkan kecepatan (rpm) alternator lebih besar dibandingkan dengan 3 sudu. Lama waktu yang dibutuhkan untuk mengisi ampere baterai sampai penuh dengan 3 sudu yaitu 1 jam 45 menit, sedangkan dengan 6 sudu waktu yang dibutuhkan hanya 1 jam 30 menit. Energi yang dihasilkan turbin angin mini dengan 6 sudu mampu untuk menghidupkan tiga buah rangkaian lampu LED (putih, merah, dan hijau) selama 125,6 jam atau sama dengan \pm 5 hari.
\end{abstract}

Kata kunci: turbin angin mini

\section{ABSTRACT}

This study aimed to determine the effect of time (day and night) on the amount of wind speed (km / h) in the study area, to know the type of wind based on average wind speed $(\mathrm{km} / \mathrm{h})$ in the study area according to Beaufort scale table, 3 blades and 6 blades on the wind turbine to rotation speed per minute (rpm) of the alternator, knowing the ratio of the battery charging time by wind turbines with 3 blades and 6 blades, knowing the time required to turn on the LED light circuit. This research was conducted by experimental method, which is conducting trials of wind turbine with 3 blades and 6 blades. Data analysis used was univariate, bivariate and advanced analysis. Time (day and night) gives influence on wind speed. Wind turbine with 6 blades produces a higher alternator (rpm) speed compared to 3 blades. The length of time required to charge the battery ampere to full with 3 blades is 1 hour 45 minutes, while with 6 blades it takes only 1 hour 30 minutes. The energy produced by a mini wind turbine with 6 blades is able to turn on three LED lights (white, red, and green) for 125.6 hours or equal to \pm 5 days.

Key words: mini wind turbine

\section{PENDAHULUAN}

Energi merupakan bagian penting dalam kehidupan masyarakat, karena hampir semua aktivitas manusia selalu membutuhkan energi. Sebagian besar energi yang digunakan di Indonesia berasal dari energi fosil yang berbentuk minyak bumi dan gas bumi. Jumlah energi fosil ini makin lama semakin berkurang dan harganya akan terus naik, sehingga perlu dicarikan sumber energi alternatif untuk membangkitkan energi listrik tersebut. (Indartono 2005 dalam Alamsyah 2007). Menurut Triharyanto (2007), banyak sekali energi alternatif dari alam terutama di Indonesia yang dapat dimanfaatkan untuk menghasilkan listrik. Salah satu alternatif energi yang dapat dipilih adalah angin, karena ngin terdapat dimana-mana sehingga mudah didapatkan serta tidak membutuhkan biaya besar. Energi listrik tidak dapat langsung dihasilkan oleh alam, maka untuk memanfaatkan energi angin ini dibutuhkan sebuah alat yang dapat merubah energi angin tersebut menjadi energi listrik. Alat yang digunakan yaitu turbin angin, dimana turbin angin ini akan 
menangkap energi angin dan menggerakkan alternator yang nantinya akan merubah energi gerak menjadi energi listrik.

Menurut Koenhardono (2009), permasalahan sistem kelistrikan pada kapal-kapal penangkap ikan di Indonesia masih kurang mendapatkan perhatian secara memadai, dimana sistem kelistrikan yang ada berdasarkan pada sistem kelistrikan di darat. ketersediaan energi listrik di kapal penangkap ikan sangat penting bagi operasional dan keselamatan kapal. Menurut dari data statistik yang di informasikan oleh IMO, ILO dan FAO bahwa 7\% kecelakaan fatal terjadi di industri penangkapan ikan dan setiap tahunnya terjadi sekitar 24.000 kecelakaan tersebut, dimana 80\% kecelakaan kapal disebabkan oleh kesalahan manusia. Salah satu faktor penyebab kapal tersebut mengalami kecelakaan yaitu kapal tersebut tidak dilengkapi dengan peralatan navigasi yang sesuai dengan aturan yang berlaku, baik secara nasional dan internasional, contohnya penggunaan lampu navigasi.

Dalam penelitian ini, dibuat suatu turbin angin mini tipe horizontal (propeller) sebagai alternatif pembangkit listrik, dengan alternator mobil yang berfungsi untuk mengubah energi gerak menjadi energi listrik. Selanjutnya, daya atau arus listrik yang dihasilkan digunakan untuk mengisi ulang baterai (accu) yang kemudian akan digunakan untuk kebutuhan listrik lampu. Lampu yang digunakan yaitu tiga buah rangkaian lampu LED (putih, merah dan hijau), dimana daya yang diperlukan oleh lampu LED ini jauh lebih hemat dibandingkan dengan lampu biasa.

Tujuan penelitian ini adalah mengetahui pengaruh waktu (siang dan malam) terhadap besarnya kecepatan angin $(\mathrm{km} / \mathrm{jam})$ di daerah penelitian, mengetahui tipe angin berdasarkan kecepatan angin $(\mathrm{km} / \mathrm{jam})$ rata-rata di daerah penelitian menurut tabel skala Beaufort, mengetahui pengaruh jumlah 3 balingbaling dan 6 baling-baling pada turbin angin terhadap kecepatan putaran (rpm) alternator dan mengetahui perbandingan lama waktu pengisian baterai oleh turbin angin dengan 3 baling-baling dan 6 baling-baling, serta, mengetahui waktu yang dibutuhkan untuk menghidupkan rangkaian lampu LED.

\section{METODE PENELITIAN}

Penelitian dilaksanakan dalam tiga tahap, tahap pertama yaitu pembuatan alat yang dilaksanakan pada bulan Juli-September 2011 di Workshop Bagian Kapal dan Transportasi Perikanan. Tahap kedua yaitu pengujian alat dan penyempurnaan alat yang dilaksanakan pada tanggal 26-28 November 2011 di Stasiun Lapang Kelautan (SLK) Palabuhanratu, Sukabumi, Jawa Barat. Tahap ketiga yaitu pengolahan data dan penyusunan hasil penelitian yang dilaksanakan pada bulan November-Desember 2011 di Fakultas Perikanan dan Ilmu Kelautan, Institut Pertanian Bogor.

Metode penelitian yang digunakan dalam penelitian ini adalah metode percobaan, yaitu melakukan uji coba turbin angin dengan jumlah baling-baling 3 dan jumlah baling-baling 6 sebagai alternatif energi sumber listrik untuk lampu navigasi kapal ikan. Data primer pada penelitian ini didapatkan dari hasil uji coba turbin angin dengan 3 baling-baling dan 6 baling-baling, dimana data yang diambil yaitu berupa data kecepatan angin $(\mathrm{km} / \mathrm{jam})$, kecepatan putaran alternator ( $\mathrm{rpm})$, dan arus yang dihasilkan oleh baling-baling (Ampere). Data sekunder pada penelitian ini yaitu data kecepatan angin rata-rata di Palabuhanratu, literatur dari skripsi, jurnal dan media lainnya yang berhubungan dengan judul penelitian.

Pengumpulan data penelitian ini dilakukan dengan cara pengamatan (observation), yaitu dengan cara mengamati turbin angin 3 baling-baling dan 6 baling-baling, adapun hal yang diamati pada penelitian ini yaitu sebagai berikut:

(1) Kecepatan angin $(\mathrm{km} / \mathrm{jam})$ dan arah angin

Nilai kecepatan angin dan arah angin didapatkan dengan menggunakan anemometer 3 mangkok, kemudian anemometer tersebut dipasang di atas menara mercusuar kecil dengan tinggi sekitar \pm 4 meter, dengan kabel dihubungkan langsung ke laptop, kemudian dengan menggunakan software kecepatan angin, nilai kecepatan angin dan arah angin di daerah penelitian dapat terbaca dan tersimpan secara otomatis tiap 5 menit sekali dengan satuan $\mathrm{km} / \mathrm{jam}$.

(2) Kecepatan putaran (rpm) alternator

Nilai kecepatan putaran alternator didapatkan dengan menggunakan alat Tachometer dengan modus optik, cara penggunaannya yaitu dengan menempelkan kertas sensor pada puli yang menghubungkan baling-baling dengan alternator, kemudian alat tersebut ditembakkan ke bagian kertas sensor yang telah 
menempel pada puli, sehingga setiap puli tersebut berputar per menit maka akan terbaca dan muncul pada layar Tachometer tersebut.

(3) Arus (ampere) yang dihasilkan

Arus yang dihasilkan dari turbin angin didapatkan dengan menggunakan alat Ampere meter Gauge, sebelum arus yang dihasilkan dari alternator masuk langsung ke baterai, terlebih dahulu melalui ampere meter yang dipasang pada kabel positif yang terhubung dengan alternator, sehingga setiap arus yang dihasilkan dari alternator tersebut dapat terbaca pada ampere meter.

(4) Jenis angin

Sama halnya dengan arah angin, untuk jenis angin juga didapatkan langsung saat melakukan uji coba. Jenis angin ditentukan berdasarkan arah angin, jika angin datang dari darat menuju laut maka disebut angin darat. Sebaliknya, jika angin datang dari arah laut menuju daratan maka disebut angin laut.

(5) Tipe angin

Tipe angin ditentukan berdasarkan kecepatan angin, kemudian besarnya kecepatan angin yang diperoleh ditentukan tipe anginnya pada skala Beaufort.

Tahapan analisis data yang digunakan pada penelitian ini yaitu analisis univariat, analisis bivariat dan analisis lanjut:

(1) Analisis univariat

Analisis univariat yang digunakan pada penelitian ini yaitu sebagai berikut:

(a) Rata-rata kecepatan angin (Va rata-rata)

Perhitungan untuk mengetahui nilai rata-rata kecepatan angin (Va rata-rata) yaitu sebagai berikut:

$V a($ rata - rata $)=\sum V a / n$

Keterangan :

$\mathrm{Va}($ rata-rata) $\quad=$ Rata-rata kecepatan angin $(\mathrm{km} / \mathrm{jam})$

$\sum \mathrm{V}=$ Jumlah keseluruhan kecepatan angin $(\mathrm{km} / \mathrm{jam})$

$\mathrm{N}$ = Banyak data

(b) Rata-rata kecepatan putaran alternator (Val rata-rata)

Perhitungan untuk mengetahui nilai rata-rata kecepatan putaran alternator yang dihasilkan (Val rata-rata) yaitu sebagai berikut:

$\operatorname{Val}($ rata $-\mathrm{rata})=\sum \mathrm{Val} / \mathrm{n}$

Keterangan :

Val(rata-rata) $\quad=$ Rata-rata kecepatan putaran $(\mathrm{rpm})$ alternator

$\sum \mathrm{V}=$ Jumlah keseluruhan kecepatan putaran (rpm) alternator

$\mathrm{N} \quad$ = Banyak data

(c) Rata-rata keluaran arus (I rata-rata)

Perhitungan untuk mengetahui nilai rata-rata keluaran arus yang dihasilkan (Irata-rata) yaitu sebagai berikut:

$I($ rata - rata $)=\sum I / n$

Keterangan:

$\mathrm{I}$ (rata-rata) = Rata-rata arus (ampere) yang dihasilkan

$\sum \mathrm{I} \quad=$ Jumlah keseluruhan arus (ampere) yang dihasilkan

$\mathrm{N} \quad=$ Banyak data

(d) Sebaran frekuensi kecepatan angin $(\mathrm{km} / \mathrm{jam})$ pada turbin angin dengan 3 baling-baling dan 6 baling-baling.

- Range

Range $=$ Nilai maksimum - nilai minimum, atau

Range $=$ Max - Min 
- Banyak kelas (BK)

Untuk mengetahui berapa banyak kelas yang akan disusun dari data tersebut, digunakan rumus sebagai berikut:

$\mathrm{BK}=1+3.32 \log n$

Keterangan:

BK $=$ Banyak Kelas

$\mathrm{N}$ = Banyak data

- $\quad$ Selang kelas (SK)

Untuk mengetahui selang kelas atas (SA) dan selang kelas bawah (SB) dari data kecepatan angin, digunakan rumus sebagai berikut:

$\mathrm{SK}=$ Range $/ B K$

Keterangan:

SK $=$ Selang kelas

$\mathrm{BK}=$ Banyak Kelas

- Batas Kelas

Untuk mengetahui batas kelas atas (BA) dan batas kelas bawah (BB) dari selang kelas, digunakan rumus sebagai berikut :

$\mathrm{BB}=S B-1 / 2 n s t$

$\mathrm{BA}=S A+1 / 2 n s t$

Keterangan:

$\mathrm{BB}=$ Batas kelas bawah

$\mathrm{BA}=$ Batas kelas atas

$\mathrm{SB}=$ Selang kelas bawah

$\mathrm{SA}=$ Selang kelas atas

nst $=$ Nilai satuan terkecil

- Frekuensi kecepatan angin

Frekuensi kecepatan angin yang terjadi pada saat pengujian turbin angin (3 dan 6 balingbaling) dibuat dalam sebuah tabel sebaran frekuensi, tabel tersebut dihasilkan dengan menggunakan program Microsoft Excell.

- Histogram

Data yang terdapat pada tabel sebaran frekuensi dirubah dalam bentuk histogram, hal ini dilakukan agar data sebaran frekuensi kecepatan angin lebih mudah dibaca dan dipahami. Histogram sebaran frekuensi kecepatan angin tersebut dihasilkan dengan menggunakan program Microsoft Excell.

(2) Analisis bivariat

Analisis bivariat yang digunakan pada penelitian ini yaitu sebagai berikut:

(a) Hubungan kecepatan angin $(\mathrm{km} / \mathrm{jam})$ dan kecepatan putaran ( $\mathrm{rpm})$ alternator

Untuk mengetahui hubungan kecepatan angin $(\mathrm{km} / \mathrm{jam})$ berbanding lurus atau berbanding terbalik dengan kecepatan putaran (rpm) alternator saat pengujian turbin angin dengan 3 dan 6 balingbaling, maka dibuat suatu grafik hubungan dengan menggunakan program Microsoft Excell.

(b) Hubungan kecepatan putaran (rpm) alternator dan arus (ampere) yang dihasilkan

Untuk mengetahui hubungan kecepatan putaran (rpm) alternator berbanding lurus atau berbanding terbalik dengan arus (ampere) yang dihasilkan saat pengujian turbin angin dengan 3 dan 6 balingbaling, maka dibuat suatu grafik hubungan dengan menggunakan program Microsoft Excell. 
(3) Analisis lanjut

Analisis lanjut yang digunakan pada penelitian ini yaitu sebagai berikut:

(a) Pengaruh jumlah 3 dan 6 baling-baling terhadap peningkatan kecepatan putaran (rpm) alternator

Untuk mengetahui pengaruh jumlah 3 dan 6 baling-baling terhadap peningkatan kecepatan putaran (rpm) alternator, maka dibuat suatu grafik perbandingan antara kecepatan putaran (rpm) alternator yang dihasilkan oleh turbin angin dengan 3 baling-baling dan turbin angin dengan 6 baling-baling. Grafik perbandingan tersebut dihasilkan dengan menggunakan program Microsoft Excell.

(b) Pengaruh jumlah 3 dan 6 baling-baling terhadap lama waktu pengisian baterai

Untuk mengetahui pengaruh jumlah 3 dan 6 baling-baling terhadap lama waktu pengisian baterai, maka dibuat suatu grafik perbandingan antara lama waktu pengisian oleh turbin angin dengan 3 baling-baling dan turbin angin dengan 6 baling-baling. Grafik perbandingan tersebut dihasilkan dengan menggunakan program Microsoft Excell.

\section{HASIL DAN PEMBAHASAN}

Salah satu sumber energi alternatif yang dapat dimanfaatkan untuk membangkitkan energi listrik adalah angin. Angin yang tersedia secara bebas di alam merupakan sumber energi yang tidak ada habisnya, dapat dimanfaatkan sebagai sumber energi yang sistem konversinya bersifat ramah lingkungan.

Monsun merupakan angin yang memiliki osilasi 6-12 bulanan yang bertiup sepanjang tahun dan berganti arah dua kali dalam setahun, monsun memiliki ciri adanya perbedaan yang tegas antara musim basah (wet season) dan musim kering (dry season) yang pada umumnya terjadi pada bulan Desember, Januari dan Februari (DJF) dan Juni, Juli, dan Agustus (JJA). Menurut Edmund Halley (1686) dalam Chang dan Lau (1980) mengemukakan teori bahwa Monsun terjadi akibat adanya perbedaan panas antara daratan dengan lautan sebagai hasil dari zenithal march matahari.

Monsun merupakan sistem sirkulasi regional yang mempunyai variasi musiman, dengan adanya gerak semu matahari terhadap bumi secara periodik di belahan bumi utara dan selatan menyebabkan angin di wilayah Indonesia sangat dipengaruhi oleh adanya perbedaan sel tekanan tinggi dan sel tekanan rendah di benua Asia dan Australia secara bergantian, Ramage (1968) dan Prawirowardoyo (1996). Monsun di Indonesia adalah bagian dari monsun Asia dan Australia.

Angin Monsun Asia berlangsung pada saat musim dingin di belahan bumi utara khatulistiwa, umumnya terjadi pada bulan Oktober hingga April dan puncaknya pada bulan Desember, Januari, Februari, angin monsun bertiup dari daerah Siberia menuju benua Australia. Pada periode ini daerah-daerah di Indonesia yaitu daerah yang berada di sekitar Sumatera bagian selatan, Jawa, Bali, Lombok, Nusa Tenggara sampai dengan Papua, angin monsun bertiup dari Barat ke Timur. Daerah ini disebut monsun dingin dari belahan bumi utara ini dinamakan monsun barat dan musimnya disebut musim monsun barat. Sedangkan daerah yang mencakup sebagian besar Sumatera dan Kalimantan Barat, angin monsun datang dari arah timur laut, angin monsun di daerah ini disebut monsun timur laut dan musimnya diberi nama musim monsun timur laut (Prawirowardoyo, 1996).

Angin Monsun Australia merupakan kondisi kebalikan dari monsun barat, yang terjadi antara bulan April hingga Oktober saat matahari berada di belahan bumi utara, menyebabkan benua Australia mengalami musim dingin, sehingga bertekanan tinggi. Sedangkan benua Asia lebih panas, sehingga tekanannya rendah. Menurut hukum Buys Ballot, angin akan bertiup dari daerah bertekanan tinggi ke daerah bertekanan rendah, sehingga angin bertiup dari benua Australia menuju benua Asia, dan karena menuju utara khatulistiwa/equator, maka angin akan dibelokkan ke arah kanan.

\section{Hasil pengamatan kecepatan angin pada turbin angin dengan 3 baling-baling dan 6 baling-baling}

Pada turbin angin dengan 3 baling-baling diketahui kecepatan angin yang terendah yaitu 15,9 $\mathrm{km} / \mathrm{jam}$ dengan arah angin dari timur pada pukul 00.15-00.30 WIB, sedangkan kecepatan angin tertinggi yaitu $25,2 \mathrm{~km} / \mathrm{jam}$ dengan arah angin dari utara pada pukul 15.45-16.00 WIB. Kecepatan angin rata-rata yang diperoleh dari turbin angin dengan 3 baling-baling yaitu sebesar $17,5 \mathrm{~km} / \mathrm{jam}$, kecepatan putaran alternator rata-rata sebesar 117,2 rpm, dan arus rata-rata yang dihasilkan sebesar 3,0 ampere. 


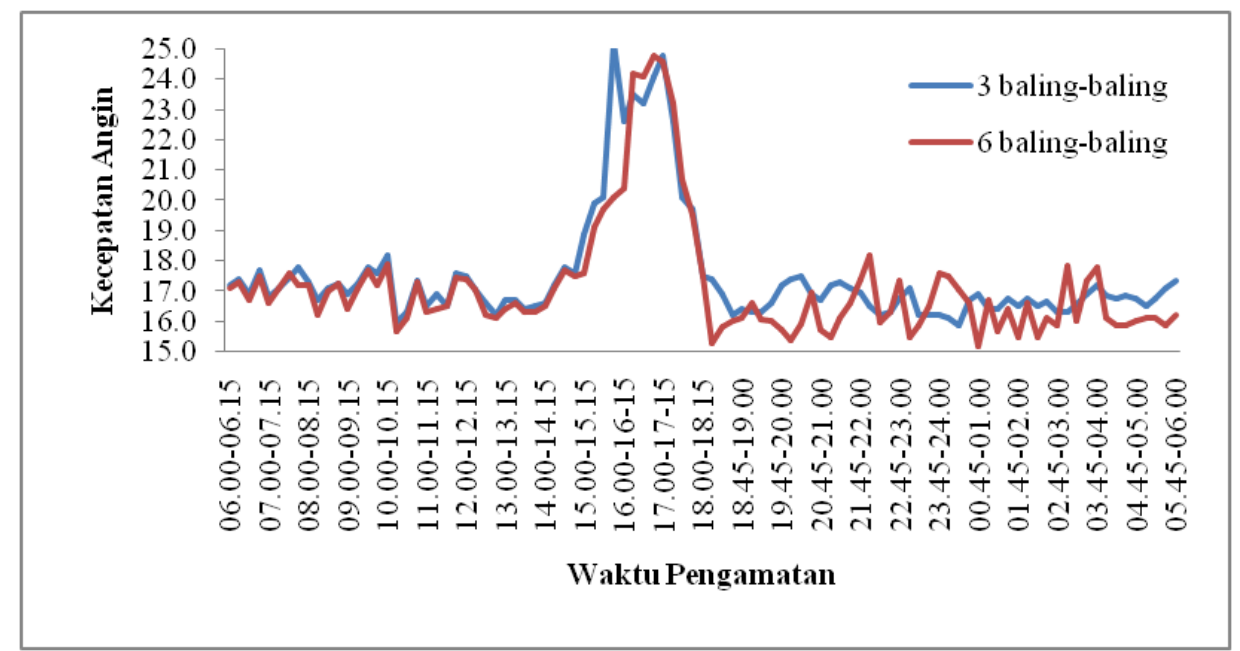

Gambar 1 Kecepatan Angin pada Turbin Angin dengan 3 Baling-baling dan 6 Baling-baling

Sedangkan, pada turbin angin dengan 6 baling-baling diketahui kecepatan angin yang terendah yaitu $15,2 \mathrm{~km} / \mathrm{jam}$ dengan arah angin dari timur pada pukul 00.45-01.00 WIB, Sedangkan kecepatan angin tertinggi yaitu 24,8 km/jam dengan arah angin dari utara pada pukul 16.45-17.00 WIB. Kecepatan angin rata-rata yang diperoleh dari turbin angin dengan 6 baling-baling yaitu sebesar 17,2 km/jam, kecepatan putaran alternator rata-rata sebesar $124,8 \mathrm{rpm}$, dan arus rata-rata yang dihasilkan sebesar 3,44 ampere. Berdasarkan hal tersebut, waktu (siang dan malam) memberikan pengaruh terhadap besarnya kecepatan angin yang bertiup di suatu daerah. Hal ini sesuai dengan pernyataan Safarudin (2003) yang diacu oleh Alamsyah (2007), yang menyatakan bahwa kecepatan angin akan berfluktuasi terhadap waktu dan tempat. Di Indonesia misalnya kecepatan angin di siang hari bisa lebih kencang dibandingkan malam hari. Di beberapa lokasi bahkan pada malam hari tidak terjadi gerakan udara yang signifikan.

Tipe angin dan jenis angin berdasarkan skala Beaufort pada saat pengujian turbin angin dengan 3 dan 6 baling-baling

(a) Tipe angin

Tabel 1 Rata-rata kecepatan angin pada saat pengujian turbin angin dengan 3 baling-baling dan 6 balingbaling.

\begin{tabular}{|c|c|c|c|}
\hline \multicolumn{2}{|c|}{ Rata-rata kecepatan angin (km/jam) } & \multirow{2}{*}{ Skala Beaufort } & \multirow{2}{*}{ Tipe Angin } \\
\hline 3 baling-baling & 6 baling-baling & & \\
\hline 17,5 & 17,2 & 3 & Angin Lemah \\
\hline
\end{tabular}

Kecepatan angin rata-rata pada turbin angin dengan 3 baling-baling dan 6 baling-baling masingmasing sebesar 17,5 dan 17,2 km/jam. Kecepatan angin rata-rata keduanya berkisar antara $12-19 \mathrm{~km} / \mathrm{jam}$ yang artinya memiliki nilai skala Beaufort 3 dan termasuk tipe angin lemah. Maka, kecepatan angin ratarata di Palabuhanratu pada saat penelitian berkisar antara $12-19 \mathrm{~km} / \mathrm{jam}$ dan termasuk tipe angin lemah. Hal ini sesuai dengan pernyataan Safarudin (2003) yang diacu oleh Alamsyah (2007), yang menyatakan bahwa pada musim-musim peralihan baik musim peralihan I (Maret-Mei) maupun musim peralihan II (September-November) matahari bergerak melintasi khatulistiwa, sehingga angin menjadi lemah dan arahnya tidak menentu.

(b) Jenis angin

Tabel 2 Jenis angin pada saat pengujian turbin angin dengan 3 baling-baling dan 6 baling-baling.

\begin{tabular}{ccc}
\hline & Waktu (Jam) & Jenis Angin \\
\hline baling-baling & 6 baling-baling & Angin laut \\
$17.45-06.00$ & $05.45-17.30$ & Angin darat \\
\hline
\end{tabular}

Pada turbin angin dengan 3 baling-baling, pukul 06.00-17.45 angin bertiup dari arah laut menuju daratan yang berarti masuk dalam jenis angin laut. Pada pukul 17.45-06.00 angin bertiup dari darat menuju 
lautan yang berarti masuk dalam jenis angin darat. Sedangkan pada turbin angin dengan 6 baling-baling, pukul 05.45-17.30 angin bertiup dari arah laut menuju daratan yang berarti masuk dalam jenis angin laut. Pada pukul 17.30-05.45 angin bertiup dari darat menuju lautan yang berarti masuk dalam jenis angin darat.

Hal ini sesuai dengan pernyataan Wyrtki (1961) yang diacu oleh Suardi (2008), yang menyatkan bahwa angin laut terjadi ketika pada pagi hingga menjelang sore hari, daratan menyerap energi panas lebih cepat dari lautan sehingga suhu udara di darat lebih panas daripada di laut, akibatnya udara panas di daratan akan naik dan digantikan udara dingin dari lautan. Sedangkan, angin darat terjadi ketika pada malam hari energi panas yang diserap permukaan bumi sepanjang hari akan dilepaskan lebih cepat oleh daratan (udara dingin), sementara itu di lautan energi panas sedang dalam proses dilepaskan ke udara. Gerakan konvektif tersebut menyebabkan udara dingin dari daratan bergerak menggantikan udara yang naik di lautan sehingga terjadi aliran udara dari darat ke laut, dan biasanya angin darat terjadi pada tengah malam dan dini hari.

Hubungan kecepatan angin dan kecepatan putaran alternator pada turbin angin dengan 3 balingbaling dan 6 baling-baling

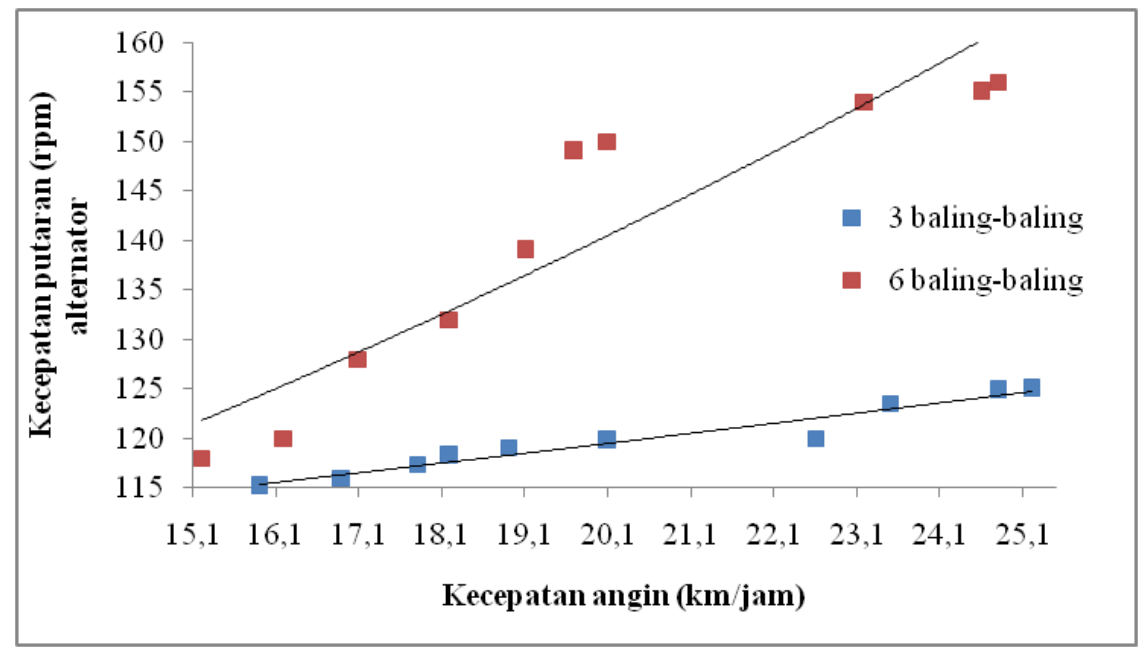

Gambar 2 Kecepatan Angin dan Kecepatan Putaran Alternator pada Turbin Angin dengan 3 Baling-baling dan 6 Baling-baling

Pada turbin angin dengan 3 baling-baling, saat kecepatan angin 15,9 km/jam kecepatan putaran (rpm) alternatornya sebesar 115,1 rpm. Saat kecepatan angin 16,9 km/jam kecepatan putaran (rpm) alternatornya sebesar $116,0 \mathrm{rpm}$, saat kecepatan angin $17,8 \mathrm{~km} / \mathrm{jam}$ kecepatan putaran (rpm) alternatornya 117,3 rpm, dan puncaknya pada saat kecepatan angin sebesar 18,2 km/jam kecepatan putaran (rpm) alternatornya 118,2 rpm. Pada turbin angin dengan 6 baling-baling, saat kecepatan angin 15,2 km/jam kecepatan putaran (rpm) alternatornya sebesar 118,0 rpm. Saat kecepatan angin 16,2 km/jam kecepatan putaran (rpm) alternatornya sebesar 120,0 rpm, saat kecepatan angin 17,1 km/jam kecepatan putaran (rpm) alternatornya $128,0 \mathrm{rpm}$, dan puncaknya pada saat kecepatan angin sebesar $24,8 \mathrm{~km} / \mathrm{jam}$ kecepatan putaran (rpm) alternatornya 156,0 rpm.

Berdasarkan hal di atas, pada turbin angin dengan 3 baling-baling maupun dengan 6 baling-baling terlihat adanya peningkatan perubahan pada setiap kecepatan angin $(\mathrm{km} / \mathrm{jam})$ dan kecepatan putaran $(\mathrm{rpm})$ alternator yang dihasilkan. Meskipun perubahan tersebut hanya sedikit, namun menunjukkan adanya perubahan yang terjadi dipengaruhi oleh kecepatan angin $(\mathrm{km} / \mathrm{jam})$ yang membuat alternator tersebut bisa berputar. Hal ini sesuai dengan pernyataan Alamsyah (2007), yang menyatakan bahwa kecepatan angin $(\mathrm{km} / \mathrm{jam})$ sangat berpengaruh terhadap kecepatan putaran $(\mathrm{rpm})$ alternator. Dimana, semakin tinggi kecepatan angin ( $\mathrm{km} / \mathrm{jam})$ diikuti dengan semakin cepatnya putaran (rpm) alternator.

\section{Hubungan kecepatan putaran alternator dan arus yang dihasilkan pada turbin angin dengan 3 baling-baling dan 6 baling-baling}

Turbin angin dengan 3 baling-baling saat kecepatan putaran alternatornya 115,1 rpm menghasilkan arus sebesar 2,8 ampere, pada saat kecepatan putaran alternator 116,0 rpm menghasilkan arus sebesar 2,9 ampere, pada saat kecepatan putaran alternator $117,3 \mathrm{rpm}$ menghasilkan arus sebesar 3,0 ampere, pada saat kecepatan putaran alternator 118,2 rpm menghasilkan arus sebesar 3,1 ampere dan pucaknya yaitu pada saat kecepatan putaran alternator 125,0 rpm menghasilkan arus sebesar 3,4 ampere. 


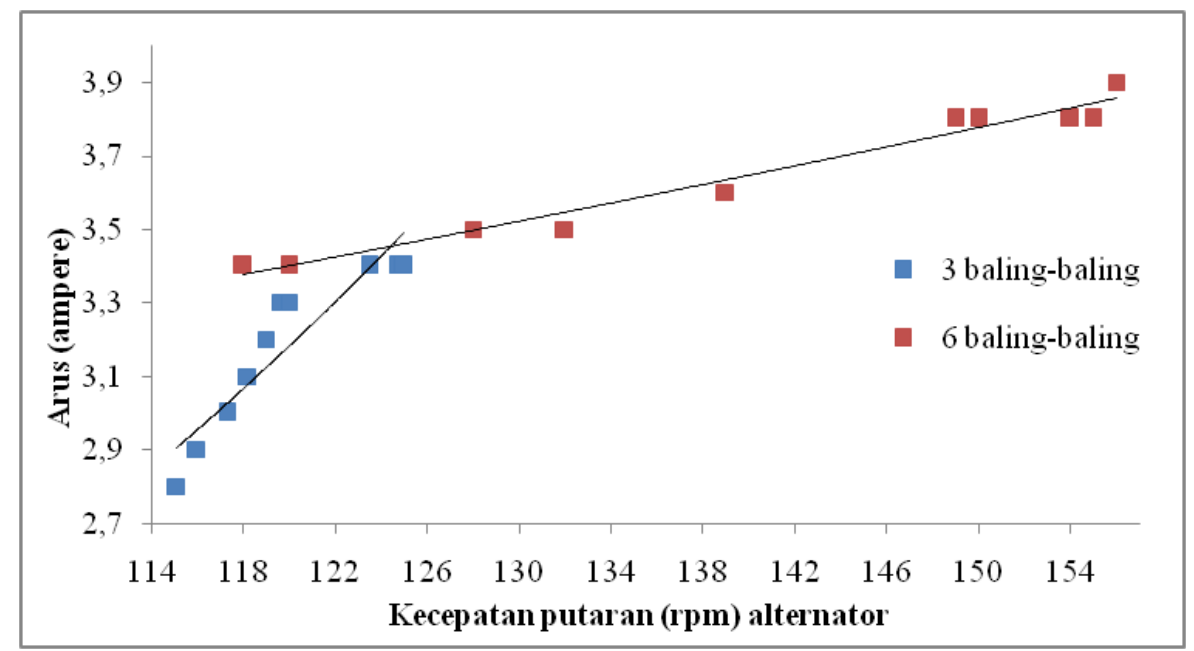

Gambar 3 Kecepatan Putaran Alternator dan Arus yang Dihasilkan pada Turbin Angin dengan 3 Balingbaling dan 6 Baling-baling

Turbin angin dengan 6 baling-baling saat kecepatan putaran alternatornya 118,0 rpm menghasilkan arus sebesar 3,4 ampere, pada saat kecepatan putaran alternator 120,0 rpm menghasilkan arus sebesar 3,4 ampere, pada saat kecepatan putaran alternator 128,0 rpm menghasilkan arus sebesar 3,5 ampere, pada saat kecepatan putaran alternator 132,0 rpm menghasilkan arus sebesar 3,5 ampere dan puncaknya yaitu pada saat kecepatan putaran alternator 156,0 rpm menghasilkan arus sebesar 3,9 ampere.

Berdasarkan hal tersebut, pada turbin angin dengan 3 baling-baling maupun dengan 6 baling-baling terlihat adanya peningkatan perubahan pada setiap kecepatan putaran (rpm) alternator dan arus (ampere) yang dihasilkan. Meskipun perubahan tersebut hanya sedikit, namun menunjukkan adanya perubahan yang terjadi dipengaruhi oleh kecepatan putaran (rpm) alternator yang menyebabkan adanya arus (ampere) yang masuk ke dalam baterai (accu). Sehingga hal ini sesuai dengan pernyataan Alamsyah (2007), yang menyatakan bahwa pada alternator mobil, saat rpm rendah maka keluarannya akan rendah. Sebaliknya, semakin tinggi rpm maka keluarannya akan semakin tinggi.

\section{Pengaruh jumlah 3 baling-baling dan 6 baling-baling terhadap peningkatan kecepatan putaran} (rpm) alternator

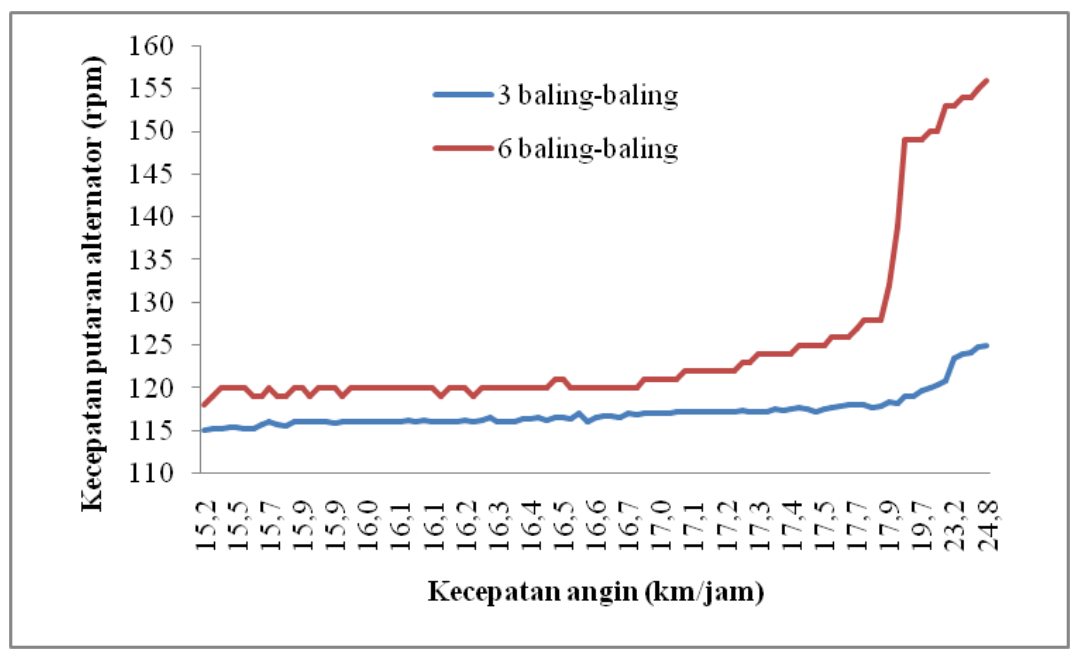

Gambar 4 Jumlah 3 Baling-baling dan 6 Baling-baling terhadap Peningkatan Kecepatan Putaran (rpm) Alternator

Pada saat kecepatan angin tertentu maka kecepatan putaran (rpm) alternator yang dihasilkan oleh turbin angin dengan 3 baling-baling lebih kecil dibandingkan dengan kecepatan putaran (rpm) alternator yang dihasilkan oleh turbin angin dengan 6 baling-baling. Berdasarkan hal tersebut, jumlah baling-baling memberikan pengaruh nyata terhadap peningkatan kecepatan putaran (rpm) alternator. Menurut Jhon 
(1985) yang diacu oleh Guntoro (2008), menyatakan bahwa semakin besar luas baling-baling maka akan menghasilkan gaya yang besar pula. Akibatnya akan menyebabkan putaran rotor yang semakin cepat dan menghasilkan daya listrik keluaran yang semakin besar. Demikian pula, dengan menambah jumlah balingbaling akan menambah luas baling-baling yang berarti akan menambah gaya $\mathrm{F}$ pada turbin sehingga akan memperbesar putaran rotor.

\section{Perbandingan lama waktu pengisian baterai oleh turbin angin dengan 3 baling-baling dan 6 baling-} baling

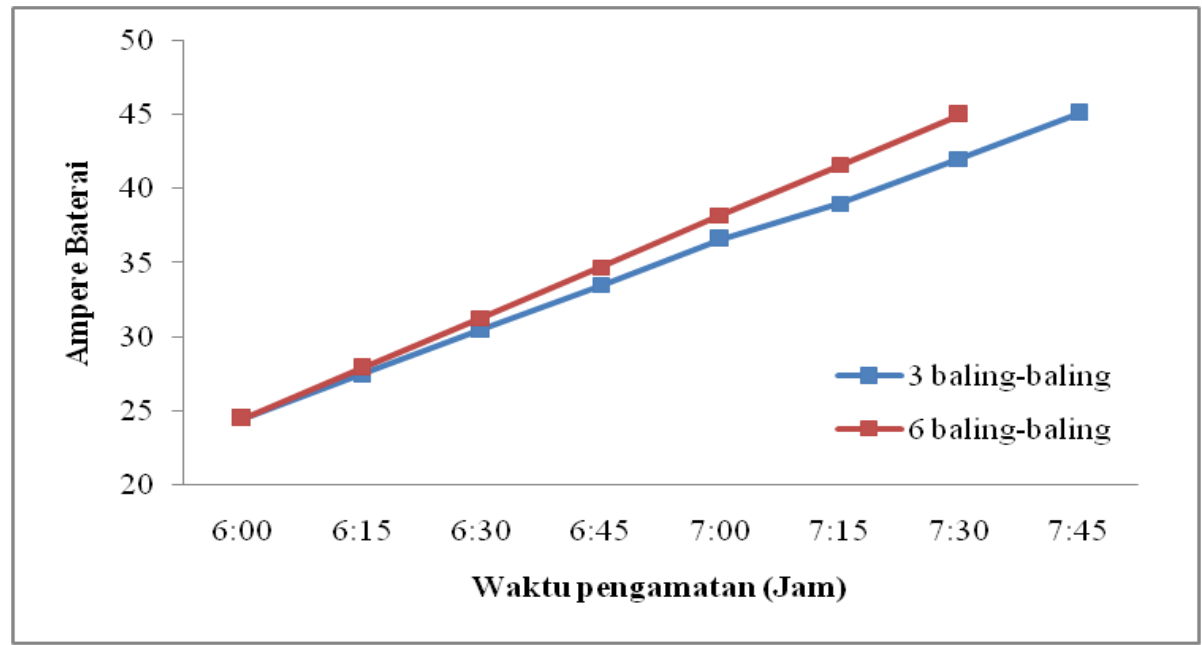

Gambar 5 Lama Waktu Pengisian Baterai oleh Turbin Angin dengan 3 Baling-baling dan 6 Baling-baling

Lama waktu yang dibutuhkan untuk mengisi baterai dengan menggunakan turbin angin 3 balingbaling lebih lambat dibandingkan turbin angin dengan menggunakan 6 baling-baling. Dengan menggunakan turbin angin 3 baling-baling, pada pukul 07.45 ampere baterai baru terisi sampai 45,1 ampere yang artinya membutuhkan waktu 1 jam 45 menit untuk mengisi ampere baterai sampai penuh. Sedangkan dengan menggunakan 6 baling-baling, pada pukul 07.30 ampere baterai baru sudah terisi penuh sampai 45,0 ampere yang artinya butuh waktu lebih cepat untuk mengisi ampere baterai sampai penuh yaitu 1 jam 30 menit. Hal ini sesuai dengan pernyataan Guntoro (2008), bahwa semakin banyak jumlah baling-baling efisiensi daya listriknya cenderung semakin besar. Hal ini terjadi karena gaya angkat angin menjadi besar dengan bertambahnya luas baling-baling (luas bertambah karena jumlah baling-balingnya bertambah) sehingga kecepatan putaran rotor (alternator) juga semakin lebih besar, akibatnya daya dan arus listrik yang dihasilkan juga semakin besar.

\section{Waktu yang dibutuhkan untuk menghidupkan rangkaian lampu LED}

Berdasarkan perhitungan, tegangan dari satu rangkaian lampu LED tersebut yaitu 1,98 V dengan daya 0,04752 Watt. Sedangkan, turbin angin dengan 6 baling-baling menghasilkan rata-rata tegangan sebesar 5,2 volt dengan rata-rata arus yang dihasilkan sebesar 3,4 ampere. Maka, daya yang dikeluarkan oleh turbin angin dengan 6 baling-baling sebesar 17,9 watt per jam. Dengan daya per jam yang dihasilkan oleh tubin angin tersebut, mampu untuk menghidupkan tiga buah rangkaian lampu LED (putih, merah, dan hijau) dengan daya sebesar 0,14256 Watt selama 125,6 jam atau sama dengan kurang lebih 5 hari.

\section{KESIMPULAN DAN SARAN}

Kesimpulan yang dapat diambil dari penelitian ini yaitu:

(1) Waktu (siang dan malam) memberikan pengaruh terhadap besarnya kecepatan angin di daerah penelitian.

(2) Menurut tabel skala Beaufort, tipe angin di daerah penelitian pada saat melakukan pengamatan termasuk dalam tipe angin lemah.

(3) Jumlah baling-baling memberikan pengaruh terhadap peningkatan kecepatan putaran (rpm) alternator, dimana turbin angin dengan 6 baling-baling menghasilkan kecepatan putaran alternator lebih besar dibandingkan turbin angin dengan 3 baling-baling. 
(4) Lama waktu yang dibutuhkan untuk mengisi ampere baterai sampai penuh oleh turbin angin dengan 3 baling-baling yaitu 1 jam 45 menit, sedangkan oleh turbin angin dengan 6 baling-baling waktu yang dibutuhkan hanya 1 jam 30 menit. Jadi, turbin angin dengan 6 baling-baling menghasilkan arus (ampere) yang lebih besar.

(5) Energi yang dihasilkan turbin angin mini dengan 6 baling-baling mampu untuk menghidupkan tiga buah rangkaian lampu LED (Putih, Merah, dan Hijau) selama 125,6 jam atau sama dengan \pm 5 hari.

Adapun saran pada penelitian ini adalah sebagai berikut:

(1) Untuk penelitian selanjutnya yang menggunakan turbin angin diharapkan pengujian dilakukan pada saat musim ketika angin besar, agar didapatkan hasil yang lebih maksimal.

(2) Desain turbin angin diharapkan dapat menyesuaikan dengan kondisi daerah penelitian.

(3) Turbin angin mini ini diharapkan dapat menjadi sumber energi alternatif untuk sistem kelistrikan pada kapal penangkap ikan khususnya untuk kebutuhan listrik lampu navigasi.

\section{DAFTAR PUSTAKA}

Alamsyah, Hery. 2007. Pemanfaatan Turbin Angin Dua Sudu Sebagai Penggerak Mula Alternator Pada Pembangkit Listrik Tenaga Angin [Skripsi]. Teknik Elektro Fakultas Teknik Universitas Negeri Semarang. Semarang.

Anonim.2008.http://idkf.bogor.net/yuesbi/eDU.KU/edukasi.net/Fenomena.Alam/Jenis.Angin/semua.html [26 Oktober 2011].

Chang CP, Lau KM. 1980. Northeasterly cold surges and nearequatorial disturbanceso ver the winter MONEX area during December 1974, part II, Planetary-scalea spects, M on. Weather. Rev. 108. 298-312.

Guntoro, Wagito. 2008. Studi Pengaruh Panjang dan Jumlah Baling-baling Terhadap Efisiensi Daya Listrik Pada Pembangkit Listrik Tenaga Angin [Tesis]. Program Studi Fisika Institut Teknologi Bandung. Bandung.

Kamus Besar Bahasa Indonesia, Pusat Bahasa Departemen Pendidikan Nasional Republik Indonesia. http://www.pusatbahasa.kemdiknas.go.id. [13 Januari 2012]

Koenhardono, Eddy Setyo. 2009. Analisa Kondisi Sistem Kelistrikan Pada Kapal Ikan (Studi Kasus Pada KM. Baruna 30GT). Seminar Nasional Perikanan Indonesia 2009. Sekolah Tinggi Perikanan. Jakarta.

Kuniyo, S. 2006. LED Sebagai Sumber Cahaya Masa Depan. www.usmankuniyo.multiply.com. [17 Februari 2011].

Prawirowardoyo, S. 1996. Meteorologi. Penerbit ITB. Bandung.

Ramage., 1968. Role of a tropical 'maritime continent' in the atmospheric circulation, Monthly Weather Review. 96. 365-369.

Routledge, G. 2002. Lighting The Way To A Low-Energy Future. IEE Review Volume 48.

Setiono, Puji. 2006. Pemanfaatan Alternator Mobil Sebagai Pembangkit Listrik Tenaga Angin [Skripsi]. Teknik Elektro Fakultas Teknik Universitas Negeri Semarang. Semarang.

Suardi, Yogi. 2009. Pola Umum Angin di Indonesia. http://www.ilmukelautan.com/oseanografi/fisikaoseanografi/405-pola-umum-angin-di-indonesia [20 Desember 2011].

Triharyanto, dkk. 2007. Kincir Angin Sumbu Horisontal Bersudu Banyak [Skripsi]. Jurusan Teknik Mesin Universitas Sanata Dharma Yogyakarta. Yogyakarta. 